Original Research Paper

\title{
Screening and Molecular Identification of Phosphate-Solubilizing Rhizobacteria from Mangrove Ecosystem of the Lombok Island
}

\author{
Lalu Zulkifli ${ }^{1}$, Prapti Sedijani ${ }^{1}$, Dewa Ayu Citra Rasmi ${ }^{1}$, Lalu Wira Zain Amrullah ${ }^{2}$ \\ ${ }^{1}$ Program Studi Pendidikan Biologi, FKIP Universitas Mataram, Mataram, Indonesia; \\ ${ }^{2}$ Program Studi PGSD FKIP Universitas Mataram, Mataram, Indonesia.
}

\author{
Article History \\ Received : February $28^{\text {th }}, 2020$ \\ Revised : April $08^{\text {th }}, 2020$ \\ Accepted : August 25 $5^{\text {th }}, 2020$ \\ Published : October $20^{\text {th }}, 2020$ \\ *Corresponding Author: \\ Lalu Zulkifli, \\ Universitas Mataram, Mataram, \\ Indonesia \\ Email: \\ lalu_zulkifli@unram.ac.id
}

\begin{abstract}
Phosphate solubilizing rhizobacteria can be used as a component in biofertilizer formulations to increase local and national food production without causing adverse risks to the environment compared to the use of chemical fertilizers. In this regard, screening and identification of phosphate solubilizing bacteria from the rhizosphere of several mangrove species that grow on the coast of Lombok Island has been carried out. The method of isolation used is the Pikovskaya method. Screening and identification activities have obtained 5 isolates of mangrove rhizosphere bacteria (BRM) which are indicated by their ability to form clear zones on Pikovskaya media, namely isolates BRM1 and BRM4 (isolated from the rhizosphere of Avicennia marina), BRM2 and BRM3 (isolated from the rhizosphere of Rhizophora apicullata), BRM5 (isolated from the rhizosphere of $R$. stylosa). All rhizobacteria isolates were identified as Gram-positive bacteria. Molecular analysis based on the comparison of 16S rRNA gene sequences of isolates with the genome database at GenBank (NCBI) using Mega 10 software, showed that all BRM isolates occupied the same cluster as bacterial species from the Genus Paenibacillus in the dendrogram of the phylogenetic tree, namely Paenibacillus sp. JWLB1 strain, Paenibacillus sp. Strain NO13, P. cineris strain cu1-7, P. favisporus strain CHP14, with genetic distance ranging from 1.3 to 1.4. Many species of the Genus Paenibacillus are currently known to play an important roles as plant growth-promoting bacteria. The BRM isolates obtained in this study can be further developed as a biofertilizer component (inoculant) in saline and dryland agriculture.
\end{abstract}

Keywords: Rizobacteria, Phosphate Solubilazing Bacteria, 16S rRNA gene, biofertilizer.

\section{Pendahuluan}

Ketersediaan $\mathrm{P}$ yang terbatas di beberapa wilayah pertanian merupakan salah satu tantangan utama yang dihadapi pertanian saat ini. Memanfaatkan bakteri pelarut $\mathrm{P}$ (PSB) telah menjadi solusi yang muncul untuk ketersediaan $\mathrm{P}$ rhizosfer yang lebih tinggi (Elhaissoufi et al., 2020). Fosfor (P) adalah salah satu unsur penting yang diperlukan untuk pertumbuhan dan perkembangan tanaman. Unsur ini membentuk sekitar 0,2\% dari berat kering tanaman. Unsur P ini merupakan elemen kedua terbanyak setelah nitrogen sebagai nutrisi mineral yang paling umum membatasi pertumbuhan tanaman. Rata-rata, kandungan fosfor tanah adalah sekitar 0,05\% (b/b). Namun, hanya $0,1 \%$ dari fosfor ini tersedia untuk digunakan tanaman (Zhu et al.,2011). Pada tumbuhan, peran fosfor berhubungan dengan mekanisme biokimia yang menyimpan energi dan kemudian memindahkannya ke dalam sel-sel hidup diantaranya sebagai komponen ATP, asam nukleat, dan banyak substrat metabolisme, serta sebagai kofaktor enzim. Selain itu fosfor juga berpartisipasi dalam fosforilasi berbagai senyawa intermediat dalam proses fotosintesis dan respirasi (Taiz \&Zeiger, 2010).

Secara tradisional, tanah yang defisiensi fosfat dapat diatasi melalui pemberian pupuk fosfat. Namun, sebagian besar pupuk fosfat tersebut tidak tersedia untuk tanaman dan pemberian pupuk anorganik yang berlebihan dapat menyebabkan masalah lingkungan seperti, kontaminasi air tanah dan eutrofikasi saluran air (Kang et al.,2011). Oleh karena itu perlu strategi yang memungkinkan dapat meningkatkan efisiensi pemupukan fosfor sehingga dapat meningkatkan hasil panen dan mengurangi masalah lingkungan.

Mikroorganisme tanah dapat meningkatkan peroleha n nutrisi oleh tanaman. Mikroorganisme tanah 
ini terlibat dalam berbagai proses biologis termasuk transformasi nutrisi dalam tanah yang tidak larut (Babalola and Glick, 2012; Sharma et al., 2013). Beberapa mikroorganisme mampu melarutkan dan memineralisasi fosfor tanah yang tidak larut menjadi tersedia untuk pertumbuhan tanaman. Disamping pemupukan dengan cara kimiawi (pemberian pupuk anorganik), pelarutan fosfat dan mineralisasi oleh mikroba adalah satu-satunya cara yang mungkin untuk meningkatkan ketersediaan fosfat bagi tanaman. Di alam banyak mikroorganisme tanah dan rhizosfer yang efektif dapat melepaskan fosfat dari total fosfat tanah melalui solubilisasi dan mineralisasi (Bhattacharyya and Jha, 2012). Kelompok mikroorganisme ini disebut sebagai mikroba pelarut fosfat (phosphate-solubilizing microbes/PSM), termasuk banyak spesies jamur dan bakteri. PSM meningkatkan ketersediaan hayati fosfat dalam tanah untuk dapat digunakan oleh tanaman. (Zhu et al., 2011).

Efisiensi pupuk P di seluruh dunia adalah sekitar 10-25\% dan konsentrasi $\mathrm{P}$ yang tersedia secara hayati di tanah sangat rendah mencapai level $1,0 \mathrm{mg} \mathrm{kg}^{-1}$ tanah. Tanaman dapat menyerap fosfat hanya dalam bentuk terlarut. Transformasi fosfat tak larut menjadi bentuk larut dilakukan oleh mikroorganisme. Mikroorganisme tanah memainkan peran penting dalam dinamika $\mathrm{P}$ tanah dan selanjutnya ketersediaan fosfat untuk tanaman. Bakteri pelarutan fosfat (PSB) meningkatkan pelarutan senyawa fosfor yang tidak larut melalui pelepasan asam organik dan enzim fosfatase dan phytase yang terdapat dalam berbagai mikroorganisme tanah. Selama proses konversi, bagian dari fosfor diasimilasi oleh mikroorganisme, tetapi jumlah yang dibuat larut dan dilepaskan melebihi kebutuhan mikroorganisme. Jumlah kelebihan yang dilepaskan disediakan untuk tanaman. Dari berbagai PSM yang mendiami rizosfer, bakteri pelarut fosfat (PSB) sangat berpeluang sebagai pupuk hayati yang potensial (Zaidi et al., 2009; Ahemad and Kibret, 2014).

Mikroorganisme tanah yang toleran garam atau halofilik itu juga menunjukkan kemampuan untuk melarutkan fosfor dan dapat memfasilitasi dan menjadi alternatif dalam pengembangan pertanian berbasis tanah salin-alkali. Oleh karena itu inokulasi tanah atau tanaman dengan mikroorganisme pelarut fosfat dapat menjadi strategi yang baik untuk peningkatan penyerapan fosfat oleh tanaman dan juga dapat mengurangi penggunaan pupuk kimia yang memiliki dampak negatif terhadap lingkungan (Alori et al., 2012).

Dalam kaitannya dengan keberadaan mikroba tanah, potensinya dapat digunakan untuk mempertahankan kualitas tanah melalui antara lain pemberian mikroba potensial sebagai pupuk hayati. Konsep optimasi pemanfaatan keragaman hayati (termasuk mikroba rizosfer) yang memiliki potensi tinggi sebagai pupuk hayati dalam meningkatkan status hara makro $\mathrm{N}$ dan $\mathrm{P}$ serta mengurangi kebutuhan pupuk anorganik dan meningkatkan hasil tanaman pangan seperti padi, jagung dan kedelai.

Dalam rangka menuju penggunaan mikroba pelarut fosfat dari daerah salin sebagai komponen formulasi biofertilizer dimasa yang akan datang diperlukan suatu proses awal berupa skrining dan uji kemampuan bakteri rizosfer sebagai pelarut fosfat dari daerah salin (dalam hal ini ekosistem hutan mangrove). Isolat potensial yang diperoleh ditargetkan menjadi salah satu komponen dalam formulasi biofertilizer yang dapat mendukung pertanian berbagai macam tanaman budidaya seperti kedelai dan jagung pada lahan kritis yang cukup luas di daerah Nusa Tenggara Barat. Artikel ini melaporkan hasil isolasi, karakterisasi biokimia dan identifikasi molekuler bakteri pelarut fosfat dari ekosistem mangrove yang berasal dari pantai daerah pesisir Pulau Lombok

\section{Bahan dan Metode}

\section{Isolasi Dan Penapisan Bakteri Pelarut Posfat}

Sampel tanah akan diambil di daerah ekosistem mangrove daerah pantai Selatan Pulau Lombok yang banyak ditumbuhi mangrove dari berbagai spesies. Substrat tanah yang melekat pada akar mangrove dipisahkan dengan pelan-pelan, menggunakan forsep disterilkan dan dikumpulkan kantong plastik yang steril. Sampel tanah diambil dari lokasi dan dipersiapkan untuk isolasi bakteri rizosfer pada hari yang sama. Satu gram (1g) dari setiap sampel tanah dilarutkan dalam $9 \mathrm{ml}$ air destilasi steril, disaring oleh kertas filter Whatman $125 \mathrm{~mm} .1 \mathrm{ml}$ dari larutan yang telah difilter di atas kemudian ditransfer ke dalam $9 \mathrm{ml}$ air destilasi steril untuk membentuk pengenceran $10^{-2}$. Dengan cara yang sama dilakukan pengenceran

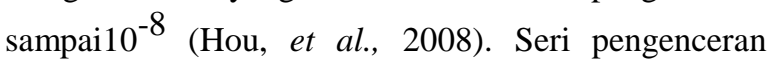
sampel tanah $10^{-4}, 10^{-5}, 10^{-6}$ disebarkan sebanyak 0,1 $\mathrm{ml}$ pada medium agar Pikovskaya mengandung tricalcium fosfat (TCP) sebagai sumber fosfat (Abhijith, et al., 2017). Komposisi media PVK (gr/L) adalah sbb :Yeast Extract (0,5), Dextrosa (10), $\left(\mathrm{NH}_{4}\right)_{2} \mathrm{SO}_{4}(0,5) \mathrm{MgSO}_{4} \cdot 7 \mathrm{H}_{2} \mathrm{O}(0,5), \quad \mathrm{Ca}_{3}\left(\mathrm{PO}_{4}\right)_{2}(5)$, $\mathrm{NaCl}(0,2), \quad \mathrm{KCl}(0,2), \quad \mathrm{MnSO}_{4} \cdot 2 \mathrm{H}_{2} \mathrm{O} \quad(0,002)$, $\mathrm{FeSO}_{4} \cdot 7 \mathrm{H}_{2} \mathrm{O}(0,002)$, Agar (15). $\mathrm{pH}$ media disesuaikan menjadi 7,0. Media PVK yang sudah disebarkan sampel selanjutnya diinkubasi dalam posisi terbalik dalam inkubator selama 7 hari pada $27-30^{\circ} \mathrm{C}$ dan koloni yang menunjukkan adanya zona terang (halo) ditandai positif untuk sebagai koloni pelarut fosfat (PSB). Zona bening ini disebabkan karena adanya 
pelarutan senyawa $\mathrm{Ca}_{3}\left(\mathrm{PO}_{4}\right)_{2}$. Koloni yang terpilih ini kemudian disubkultur (metode gores dengan media yang sama) sebanyak 2-3 kali untuk memperoleh kultur murni. Isolat selanjutnya dipindahkan kemedia agar PVK (slant) dan disimpan pada suhu $4{ }^{\circ} \mathrm{C}$ untuk studi selanjutnya.

\section{Karakterisasi Morfologi Dan Biokimia Isolat}

Adapun uji-uji yang dilakukan untuk karakterisasi biokimia dan fisiologi isolate adalah uji motilitas dan uji indol, uji hidrolisis pati, uji katalase, uji fermentasi karbohidrat, uji TSI, uji Simmom citrate (Vasanthakumari, 2009).

\section{Identifikasi Molekuler Isolat Bakteri Pelarut Fosfat} Untuk identifikasi molekuler bakteri rizosfer dilakukan dengan tahap berikut: (i) Ekstrak DNA. Untuk estraksi DNA, mengikuti prosedur Kit DNA-Zol. Hasil sentrifugasi (pelet) dikeringkan pada suhu kamar, kemudian ditambah aquades $50 \mu 1$ dan disimpan pada$20^{\circ} \mathrm{C}$ sampai saat digunakan. (ii) Amplifikasi gen 16SrRNA dengan PCR. Primer universal 16S rRNA yang digunakan adalah primer 63f (5' -CAG GCCTAA CACATG CAA GTC- 3') dan 1387r (5'GGGCGGCGTGTACAAGGC-3') (Marchesi et al., 1998). PCR dilakukan dengan cara, kedalam tabung PCR dimasukkan 2x PCR master mix solution $10 \mu \mathrm{l}$, template DNA $1 \mu \mathrm{l}$, primer 63f $1 \mu \mathrm{l}$, primer $1387 \mathrm{r} 1 \mu \mathrm{l}$, aquades $17 \mu \mathrm{l}$, selanjutnya amplifikasi DNA dilakukan dengan menggunakan alat my cycler (BioRad). Kondisi awal (pre) PCR diatur pada suhu $94^{\circ} \mathrm{C}$ selama 5 menit, selanjutnya diikuti dengan 35 siklus PCR yang terdiri dari denaturasi pada suhu $94^{\circ} \mathrm{C}$ selama 30 detik, annealing primer pada suhu $55^{\circ} \mathrm{C}$ selama 30 detik dan ekstensi pada suhu $72^{\circ} \mathrm{C}$ selama 45 detik. Setelah 35 siklus terlampaui, dilakukan post PCR pada suhu $72^{\circ} \mathrm{C}$ selama 5 menit dan disimpan pada suhu $20^{\circ} \mathrm{C}$ (Sepriana et al., 2020). (iii) Elektroforesis. Pada tahap elektroporesis, sebanyak $4 \mu \mathrm{l}$ produk PCR dielektroforesis pada $2 \%$ gel agarose dalam buffer TBE $(0,5 \mathrm{TBE})$ yang telah diisi sebanyak $4 \mu \mathrm{l} \mathrm{EtBr}$. Elektroforesis dilakukan pada tegangan $100 \mathrm{~V}$ dan kuat arus sebesar 400 A selama 30 menit. Marker yang dipakai adalah 100 bp DNA ledder. Hasil elektroforesis divisualisasi dibawah sinar ultraviolet dan difoto dengan menggunakan GelDoc. (iv) Sekuensing produk PCR. Produk PCR yang diperoleh selanjutnya disekuensing di 1stBase Malaysia melalui PT Genetika Science Jakarta.

\section{Teknik Analisa data}

Teknik pengumpulan data penelitian ini dilakukan dengan pengamatan karakteristik morfologi dan biokimia isolat. Data sekuen dianalisis dengan menggunakan software MEGA 10 dengan referensi sekuens database pada Genbank yang terdapat pada situs NCBI (http://www.nebi.nml.nih.gov).

\section{Hasil dan Pembahasan}

\section{Isolasi dan penapisan bakteri pelarut Fosfat.}

Hasil isolasi dan skrening bakteri rizosfer pelarut fosfat dan ciri morfologi koloni dan morfologi sel ditampilkan pada Gambar 1, dan dideskrpsikan pada Tabel 1. Kemampuan bakteri sebagai pelarut fosfat ditunjukkan dengan terbentuknya zona bening pada media Pikovskaya setelah inkubasi selama lebih dari 7 hari. Diperolah 5 isolat yang mengidikasikan kemapuannya dalam melarutkan fosfat. Ciri morfologi koloni bervariasi, misalnya bentuknya ada yang sirkuler dan tidak beraturan, sedangkan warnanya ada yang putih (BRM4), krem (BRM3 dan BRM5), kekuningan (BRM1 dan BRM2). Morfologi sel menunjukkan variasi dari bacil tersebar, bacil berantai dan diplococcus. Isolat BRM1 memiliki endospore sentral, sedangkan BRM2 memiliki endospora subterminal. BRM3, BRM4, dan BRM5 terlihat tidak memiliki endospore saat pengamatan. Semua isolate merupakan bakteri Gram + .

Tabel 1. Ciri Morfologi koloni dan sel isolate bakteri pelarut fosfat

\begin{tabular}{|l|l|l|l|}
\hline No & Nama Isolat & Bentuk Morfologi Koloni & Bentuk Morfologi Sel \\
\hline 1 & BRM1 & $\begin{array}{l}\text { Circular; Elevation : raised; Margin: } \\
\text { undulate; Warna : kuning }\end{array}$ & $\begin{array}{l}\text { Bacil, berantai lebih dari 2 sel, Gram +, } \\
\text { terdapat endospora sentral }\end{array}$ \\
\hline 2 & BRM2 & $\begin{array}{l}\text { Koloni tidak beraturan, tepi rizoid, warna } \\
\text { krem }\end{array}$ & $\begin{array}{l}\text { Bacill berantai lebih dari 2 sel, Gram +, } \\
\text { terdapat endospora subterminal }\end{array}$ \\
\hline 3 & BRM3 & Koloni bulat, tepi rata, warna kuning & $\begin{array}{l}\text { Bacil panjang, berantai lebih dari 2 sel, } \\
\text { Gram + }\end{array}$ \\
\hline 4 & BRM4 & $\begin{array}{l}\text { Circular; Elevation : flat, Margin: entire; } \\
\text { Warna : putih }\end{array}$ & Bacill tersebar, Gram + \\
\hline 5 & BRM5 & $\begin{array}{l}\text { Koloni bulat kecil-ceil, tepi rata, berwarna } \\
\text { crem }\end{array}$ & Diplococcus, formasi tetrad, Gram + \\
\hline
\end{tabular}

Keterangan: BRM (Bakteri Rizosfera Mangrove) 


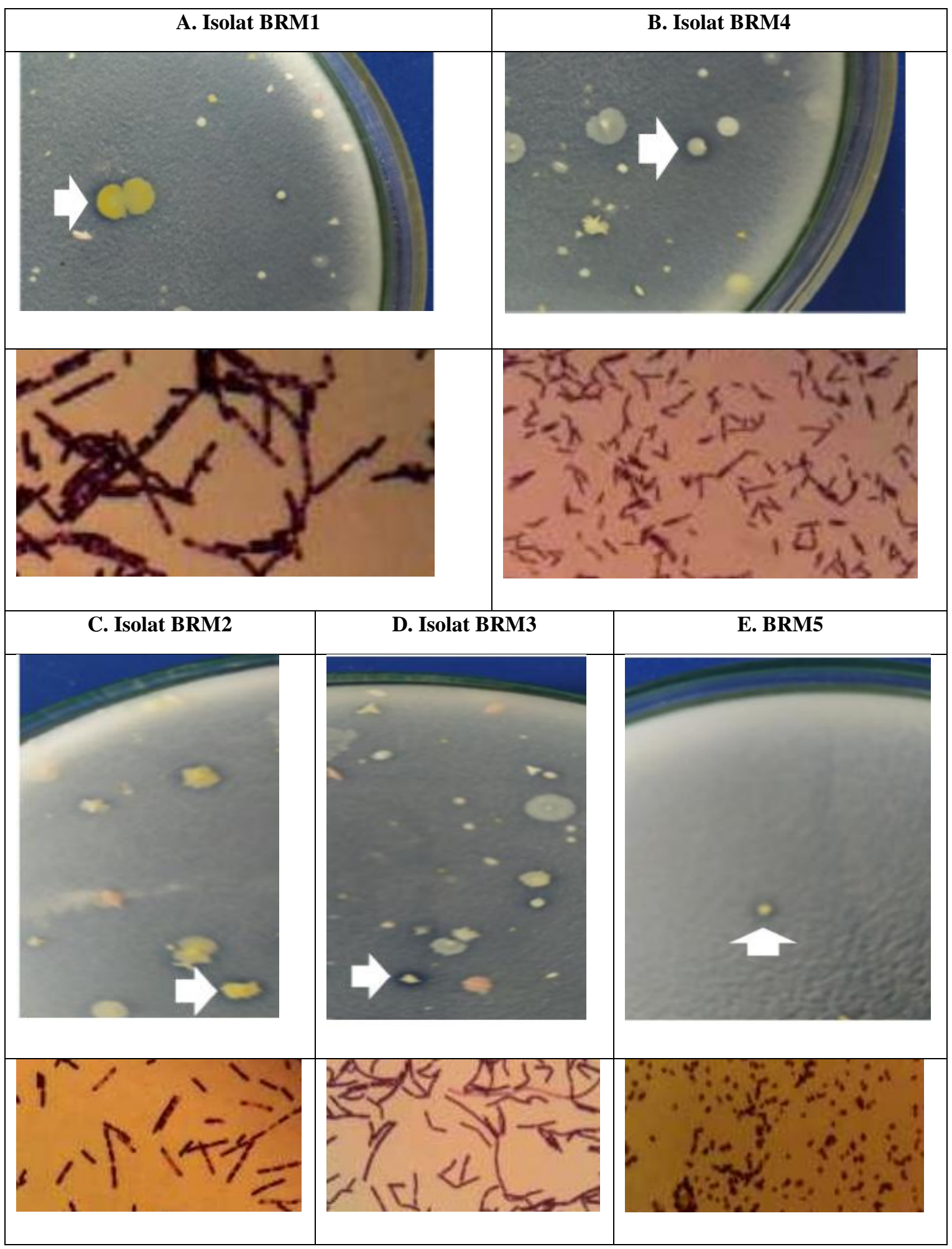

Gambar 1. Hasil isolasi dan penapisan bakteri pelarut fosfat yang diisolasi dari rizosfera hutan mangrove dari daerah pantai Lembar (tanda panah putih pada media Pikovskaya menunjukkan koloni yang positif sebagai rizobakteria pelarut fosfat). Ciri morfologi koloni (Atas) dan morfologi sel (Bawah) dari isolat BRM1 dan BRM4 hasil isolasi dari rizosfer Avicennia marina (A dan B), isolate BRM 2 dan BRM3 dari rizosfer Rhizophora apiculata (C dan D) dan BRM5 dari rizosfera Rhizophora stylosa (E). 
Berdasarkan data yang diperoleh dapat dijelaskan bahwa keberadaan rizobakteria pelarut fosfat dari daerah salin khususnya daerah hutan mangrove cukup tersebar baik pada low tidal zone (diwakili oleh rizosfer Avicennia marina) maupun pada daerah medium tidal zone (diwakili oleh Genus Rhizophora).

\section{Karakterisasi Biokimia Isolat}

Uji yang dilakukan untuk karakterisasi biokimia dan fisiologi isolate adalah uji motilitas dan uji indol, uji hidrolisis pati, uji katalase, uji fermentasi karbohidrat, uji TSI, uji Simmom citrate. Adapun hasilnya disajikan pada Tabel 2 .

Tabel 2. Hasil uji biokimia isolat rizobakteria dari rizosfer mangrove

\begin{tabular}{|c|c|c|c|c|c|c|}
\hline No & $\begin{array}{c}\text { Uji/ } \\
\text { Kode Isolat }\end{array}$ & BRM4 & BRM1 & BRM5 & BRM3 & BRM2 \\
\hline \multirow{2}{*}{1} & TSI: L/d & $\mathrm{b} / \mathrm{b}$ & $\mathrm{b} / \mathrm{b}$ & $a / b$ & $a / b$ & $\mathrm{~b} / \mathrm{a}$ \\
\hline & $\mathrm{H}_{2} \mathrm{~S} / \mathrm{Gas}$ & $-/-$ & $-/-$ & $-/-$ & $-/-$ & $-/-$ \\
\hline 2 & Simon Citrat & - & - & - & - & - \\
\hline 3 & Urea & - & - & + & + & - \\
\hline 4 & Motilitas & + & + & - & + & + \\
\hline 5 & Glukosa & - & - & - & - & - \\
\hline 6 & Sukrosa & - & + & - & + & - \\
\hline 7 & Laktosa & - & - & - & - & - \\
\hline 8 & Maltosa & - & + & - & + & - \\
\hline 9 & Manosa & - & - & - & - & - \\
\hline 10 & Indol & - & - & - & - & - \\
\hline 11 & Hidrolisis Pati & - & - & - & - & - \\
\hline 12 & $\mathrm{MR} / \mathrm{VP}$ & $-1-$ & $+/+$ & $+/-$ & $-1-$ & $+/+$ \\
\hline 13 & Katalase & - & - & - & - & - \\
\hline
\end{tabular}

Keterangan $: \mathrm{a}=$ asam, $\mathrm{b}=$ basa, $\mathrm{MR}=$ metil red, $\mathrm{VP}=$ voges proskauer

Uji fisiologi biokimia meliputi uji TSI, uji hidrolisis urea, uji simon sitrat, uji motilitas, uji karbohidrat (glukosa, sukrosa, laktosa, maltose, manosa), uji katalase, uji indol, uji hidrolisis pati, uji metil red-voges proskauer (MR-PV). Isolat BRM4 dan isolat BRM1 pada uji TSI menunjukkan sifat basa pada lereng dan dasar media. Isolat BRM5 dan BRM3 menunjukkan sifat asam pada lereng dan sifat basa pada dasar media, sedangkan isolat BRM2 hanya menunjukkan sifat basa pada dasar media. Semua isolat tidak menghasilkan $\mathrm{H}_{2} \mathrm{~S}$ dan gas. Pada uji simon citrat, glukosa, laktosa, manosa, indol, hidrolisis pati dan katalase semua isolat menunjukkan hasil negatif. Isolat BRM5 dan BRM3 menunjukkan hasil positif pada uji urea. Pada uji motilitas isolat BRM1, isolat BRM3 dan isolat BRM2 menunjukkan hasil positif yang menandakan adanya pergerakan bakteri. Isolat BRM1, isolat BRM3 dan isolat BRM2 menunjukkan hasil positif pada uji glukosa yang menandakan bakteri mampu memfermentasikan gula. Uji sukrosa dan uji maltosa pada isolat BRM1 dan isolat BRM3 menunjukkan hasil positif. Untuk uji MR/VP menunjukkan hasil positif pada isolat BRM1 dan isolat BRM2 yang menandakan adanya fermentasi asam campuran. Sedangkan pada isolat BRM5 hanya menunjukkan hasil negatif pada uji VP (voges proskauer) yang menandakan bakteri tidak mampu menghasilkan produk akhir berupa asetil metil karbonil dari fermentasi glukosa.

\section{Identifikasi Molekuler Isolat Bakteri Pelarut Fosfat dari Rizosfer Mangrove.}

Isolat bakteri rizosfer selanjutnya diidentifikasi secara molekuler, melalui tahap isolasi DNA genom dan PCR menggunakan primer universal 63f dan 1387r. Hasil dari amplifikasi dielektroforesis pada gel agarosa pada tegangan $100 \mathrm{~V}$ dan kuat arus 400 A yang diamati di bawah UV transluminator. Hasil elektroforesis (Gambar 1) memperlihatkan adanya pita DNA penyandi gen $16 \mathrm{~S}$ rRNA sejajar pada ukuran \pm 1324 bp setelah dibandingkan dengan DNA marker (100 bp DNA ladder). 


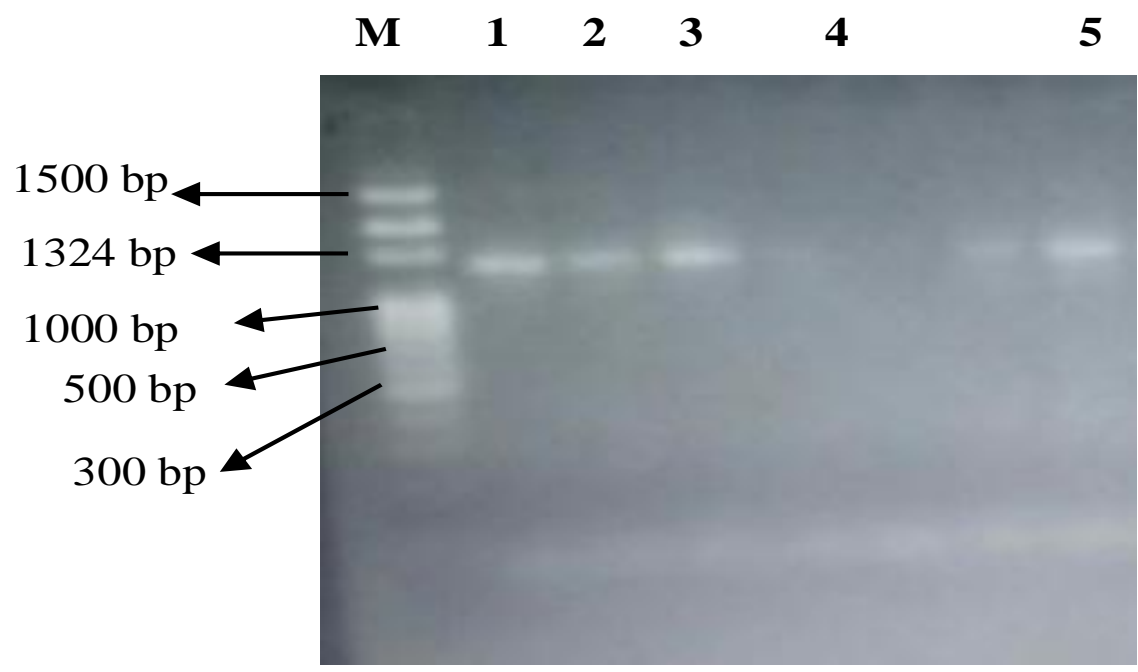

Gambar 2. Hasil elektroforesis dari amplifikasi PCR dari gen 16S rRNA isolat bakteri rizosfer mangrove (BRM) dengan ukuran pita DNA \pm 1300 bp. Keterangan : M : DNA marker (100 bp DNA ladder). Nomor 1 s/d 5 menunjukkan no isolate rizobakteri; 1. BRM1; 2. BRM2; 3. BRM3; 4. BRM4 (tidak ada produk PCR, sehingga tidak ada analisis DNA lanjutan); 5. BRM5.

Setelah itu identifikasi dilanjutkan dengan melakukan sekuensing. Kemudian data sekuen gen 16S rRNA yang berasal dari isolat bakteri rizosfer dibandingkan dengan database yang ada pada GenBank, hasil perbandingan sekuensing kemudian divisualisasikan dalam bentuk pohon filogenetik menggunakan software MEGA10 (Gambar 3).

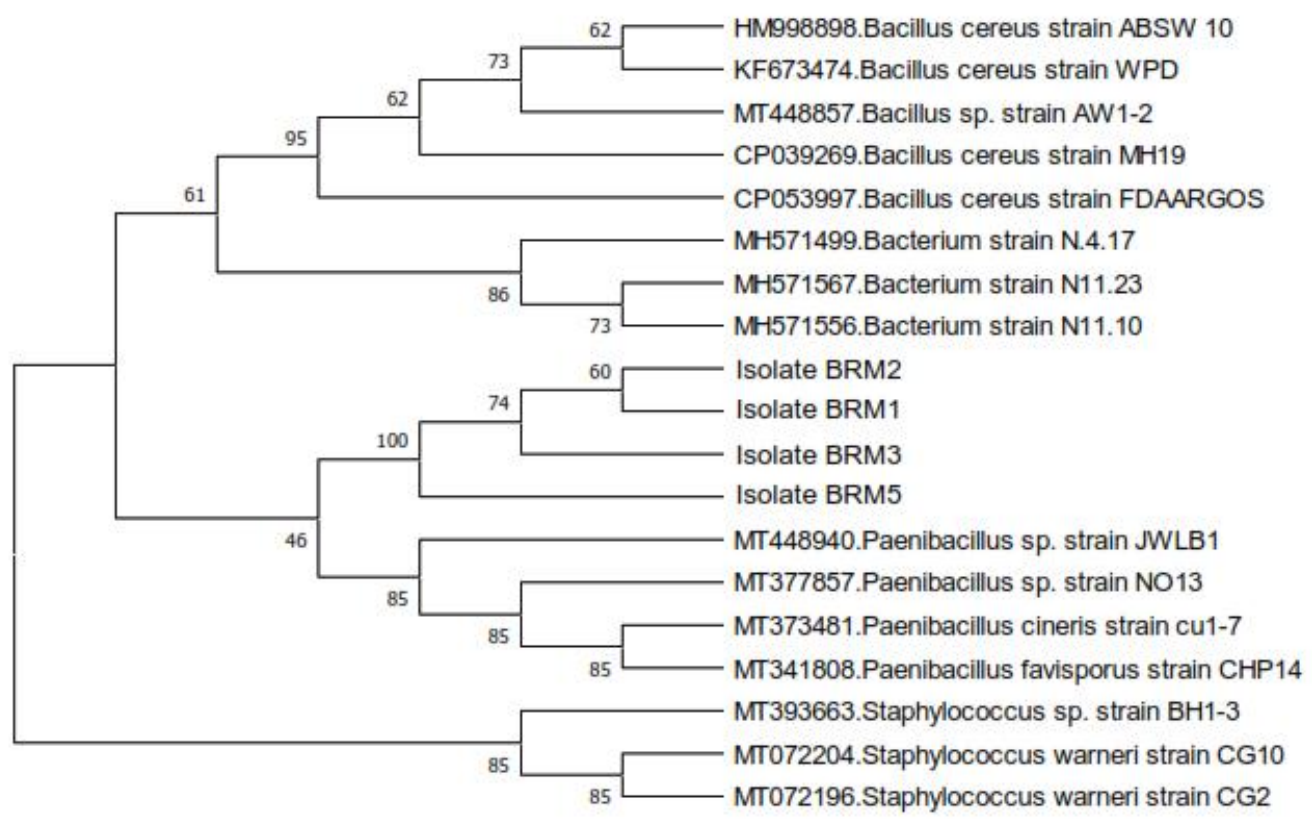

$$
\stackrel{\longmapsto}{\longmapsto .10}
$$

Gambar 3. Dendrogram filogenetik dikonstruksi dengan menggunakan metode Neighbor-Joining. Pohon konsensus bootstrap disimpulkan dari 1000 ulangan. Persentase ulangan di mana taksa termasuk dalam klaster yang sama dalam uji bootstrap (1000 ulangan) ditampilkan di sebelah cabang. Jarak evolusi dihitung menggunakan metode Kimura. 
Analisis ini melibatkan 19 urutan nukleotida dari spesies yang disebutkan pada gambar. Total dataset posisi basa yang dianalisis adalah 1046 posisi.

Tabel 2. Jarak genetik (genetic distance) isolat bakteri rizosfer mangrove (BRM) pelarut fosfat terhadap bakteri referensi berbasis sekeun gen $16 \mathrm{~S}$ rRNA yang diakses dari GenBank

\begin{tabular}{llcccc}
\hline \multirow{2}{*}{ No } & Bakteri Referensi & \multicolumn{3}{c}{ Kode Isolat Bakteri rizosfer } \\
\cline { 3 - 6 } & & BRM1 & BRM2 & BRM3 & BRM5 \\
\hline 1 & Paenibacillus_sp._strain_JWLB1 & 0,144 & 0,136 & 0,144 & 0,139 \\
\hline 2 & Paenibacillus_sp._strain_NO13 & 0,147 & 0,134 & 0,147 & 0,134 \\
\hline 3 & Paenibacillus_cineris_strain_cu1-7 & 0,143 & 0,138 & 0,142 & 0,130 \\
\hline 4 & Paenibacillus_favisporus_strain_CHP14 & 0,149 & 0,135 & 0,148 & 0,132 \\
\hline
\end{tabular}

Tabel 3. Hasil analisis jarak genetik (genetic distance) antar isolat bakteri rizosfer mangrove (BRM) pelarut fosfat berbasis sekeun gen 16S rRNA dengan MEGA10.

\begin{tabular}{cccccc}
\hline \multirow{2}{*}{ No } & \multirow{2}{*}{$\begin{array}{c}\text { Isolat } \\
\text { referensi }\end{array}$} & \multicolumn{4}{c}{ Kode isolat bakteri rizosfer } \\
\cline { 3 - 6 } & BRM1 & BRM2 & BRM3 & BRM5 \\
\hline 1 & BRM1 & & 0,003 & 0,045 & 0,081 \\
\hline 2 & BRM2 & 0,003 & & 0,043 & 0,077 \\
\hline 3 & BRM3 & 0,045 & 0,043 & & 0,081 \\
\hline 4 & BRM5 & 0,081 & 0,077 & 0,081 & \\
\hline
\end{tabular}

Berdasarkan hasil konstruksi filogenetik tree dalam bentuk dendrogram (Gambar 3) dan analisis jarak genetik, semua isolate terindikasi berkerabat dekat dengan Genus Paenibacillus, khususnya spesies Paenibacillus_sp._strain_JWLB1,Paenibacillus_sp._str ain_NO13, Paenibacillus_cineris_strain_cu1-7, Paenibacillus_favisporus_strain_CHP14. Isolat rizosfer berada dalam satu klaster dengan Genus Paenibacillus tersebut, dengan jarak genetic berkisar antara 1,3 - 1,4 (Tabel 2). Sementara itu jarak genetic antar isolate tergolong sangat dekat dengan jarak genetic 0.003 0,081 . Jarak yang paling dekat adalah antara isolate BRM1 dan BRM2 yang diisolasi dari substra rizosfera mangrove yang berbeda, dimana BRM1 diisolasi dari dari rizosfer Avicennia marina, sedangkan BRM2 diisolasi dari rizosfer Rhizophora apiculata. Isolat BRM5 yang diisolasi dari substrat rizosfera Rhizophora stylosa memiliki jarak genetic paling jauh terhadap semua isolate lainnya. Beberapa spesies yang termasuk genus Bacillus dan genus Staphyllococcus berada pada klaster yang berbeda dengan isolate yang diperolah (Gambar 3).

Paenibacillus adalah genus anaerob fakultatif yang membentuk endospora. Pada awalnya Paenobacillus termasuk dalam genus Bacillus yang kemudian usulkan untuk direklasifikasi sebagai genus baru (Ash et al., 1993). Genus Paenibacillus ini memiliki anggota spesies yang banyak tersebar diberbagai jenis lingkungan, misalnya tanah, air, rizosfer, bahan nabati, dan larva serangga. (Padda et al., 2017). Dilaporkan bahwa beberapa spesies Paenibacillus berfungsi sebagai rizobakteri pemacu pertumbuhan tanaman yang baik (PGPR), disamping itu dapat juga berperan sebagai biopestisida alami, karena bersifat antagonis terhadap patogen akar, baik bakteri maupun jamur.

PGPR dapat meningkatkan pertumbuhan tanaman melalui beberapa mekanisme langsung dan tidak langsung. Mekanisme langsung misalnya pelarutan fosfat, produksi hormone, fiksasi nitrogen, dan mendegradasi polutan. Mekanisme tidak langsung misalnya melalui pengendalian fitopatogen dengan bersaing memperebutkan sumber daya seperti asam amino, gula, atau besi, atau dapat juga menghasilkan antibiotic ataupun enzim litik (Bloemberg and Lugtenberg, 2001; Kloepper et al., 1980; Ryu et al., 2003). Persaingan untuk mendapatkan besi juga berfungsi sebagai mode selektif yang kuat yang menentukan populasi mikroba di daerah rhizosfer. Beberapa penelitian menunjukkan bahwa 
PGPR melakukan aktivitas pemacu pertumbuhan tanaman mereka dengan menghilangkan zat besi mikroflora asli. Meskipun zat besi melimpah di alam, kelarutan $\mathrm{Fe}^{3+}$ yang sangat rendah pada $\mathrm{pH} 7$, menyebabkan sebagian besar organisme menghadapi masalah untuk mendapatkan zat besi yang cukup dari lingkungannya. Dalam hal ini PGPR mengembangkan strategi dengan memproduksi dan mensekresi siderofor, senyawa pengkelat besi berafinitas tinggi.

Paenibacillus sp. dapat ditemukan di tanah atau di sekitar perakaran tanaman yang berperan sebagai PGPR dengan mengikat nitrogen, pelarut fosfat, penghasil Indol Acetic Acid (IAA) dan siderofor (Grady et al., 2016; Xie et al., 2014). Analisis genomik menunjukkan terdapat 35 strain dari \pm 18 spesies Paenibacillus mampu melarutkan fosfat melalui produksi asam glukonat (Xie et al., 2016). Karena banyak sekali kegunaan dari Paenibacillus spp ini telah banyak berimplikasi dalam penggunaannya dibidang pertanian, bioremediasi lingkungan bahkan untuk kesehatan manusia dan hewan. (Jeong et al., 2019).

Dari penjelasan di atas terlihat bahwa isolatisolat BRM yang diperoleh yang memiliki kedekatan dengan spesies pada Genus Paenibacillus memiliki potensi yang baik untuk dikembangkan sebagai salah satu komponen baik sebagai biofertilizer maupun sebagai biopestida. Dari segi morfologi koloni dan sel serta identifikasi molekuler ada kemungkinan bahwa isolat-solat yang diperoleh adalah salah satu spesies dari Genus Paenibacillus ini, karena sekuen yang dibanding bukan merupakan sekuen full dari gen 16S rRNA. Karakterisasi kemampuan isolate sebagai rizobakteri (PGPR) perlu diuji kegunaannya pada aspek lain selain sebagai pelarut fosfat. Spesiesspesies Paenibacillus spp. dapat memberikan peluang yang luas dalam menemukan sumber gen dengan potensi bioteknologi dimasa yang akan datang. Pemanfaatan bakteri rizosfer pelarut fosfat sebagai salah komponen dalam formulasi biofertilizer untuk meningkatkan produksi pangan lokal maupun nasional perlu mendapat perhatian, karena dapat menurunkan resiko yang kurang baik terhadap lingkungan dibandigkan pengunaan pupuk kimia.

\section{Kesimpulan}

Studi penapisan dan identifikasi telah mendapatkan 5 isolat bakteri rizosfer mangrove (BRM) yang mengindikasikan kemampuannya dalam membentuk zona bening pada media Pikovskaya, yaitu isolate BRM1 dan BRM4 (diisolasi dari rizosfer Avicennia marina), BRM2 dan BRM3 (diisolasi dari rizosfer Rhizopora apicullata), BRM5 (diisolasi dari rizosfer Rhizophora stylosa). Semua isolate rizobakteria tersebut tergolong bakteri dalam kelompok gram positif. Berdasarkan hasil analisis jarak genetic dan filogenetik tree semua isolate BRM termasuk satu klaster dengan spesies bakteri dari Genus Paenibacillus, dengan jarak genetic berkisar antara 1,3-1,4. Banyak spesies dari Genus Paenibacillus ini saat diketahui berpean penting sebagai plant growth promoting bacteria. Isolate BRM yang diperoleh pada studi ini dapat dikembangkan lebih lanjut sebagai salah komponen biofertilizer (inokulan) yang dapat diterapkan pertanian lahan kering dan berkadar garam tinggi.

\section{Ucapan Terima Kasih}

Terimakasih kepada Rektor Universitas Mataram atas dukungan pendanaan PNBP dari dana DIPA BLU Universitas Mataram tahun anggaran 2019, dengan nomor kontrak/perjanjian: 29320/UN18.L1/PP/2019.

\section{Referensi}

Abhijith, R., Venilla, A., and Purushothaman, CS. (2017). Occurence of Phosphate-Solubilizing Bacteria in Rhizopspheric and Pnumatophoric Sidement of Avicennia marina. International Journal of Fisheris and Aquatic Studies. https://www.fisheriesjournal.com/archives/20 17/vol5issue4/PartD/5-4-31-828.pdf

Ahemad, M. And Kibret, M., (2014). Mechanisms and applications of plant growth promoting rhizobacteria: Current perspective, Journal of King Saud University-Science (2014) 26, 120. doi: 10.1016/j.jksus.2013.05.001

Alori, E., Fawole, O., and Afolayan, A. (2012). Characterization of arbuscular mycorrhizal spores isolated from Southern Guinea Savanna of Nigeria. J. Agric. Sci. 4, 13-19. DOI: $10.5539 /$ jas.v4n7p13

Ash C, Priest FG, \& Collins MD (1993). Molecular identification of rRNA group 3 bacilli (Ash, Farrow, Wallbanks and Collins) using a PCR probe test. Proposal for the creation of a new genus Paenibacillus. Antonie Van Leeuwenhoek 1993; 64:253-260. https://doi.org/10.1007/BF00873085

Babalola, O. O., and Glick, B. R. (2012). Indigenous African agriculture and plant associated microbes: current practice and future transgenic prospects. Sci. Res. Essays 7,24312439. DOI: 10.5897/SRE11.1714

Bhattacharyya, P.N., and Jha, D.K. (2012). Plant growth-promoting rhizobacteria (PGPR): Emergence in Agriculture. World J. Microbiol. 
Biotechnol. 28, 1327-1350 DOI: $10.1007 / \mathrm{s} 11274-011-0979-9$

Bloemberg GV \& Lugtenberg BJ (2001). Molecular basis of plant growth promotion and biocontrol by rhizobacteria. Curr Opin Plant Biol 2001, 4:343-350. DOI: $10.1016 /$ S13695266(00)00183-7

Elhaissoufi W, Khourchi S, Ibnyasser A, Ghoulam C, Rchiad Z, Zeroual Y, Lyamlouli K and Bargaz A (2020) Phosphate Solubilizing Rhizobacteria Could Have a Stronger Influence on Wheat Root Traits and Aboveground Physiology Than Rhizosphere P Solubilization. Front. Plant Sci. 11:979. doi: 10.3389/fpls.2020.00979

Grady, E. N., MacDonald, J., Liu, L., Richman, A., \& Yuan, Z. C. (2016). Current knowledge and perspectives of Paenibacillus: A review. Microbial Cell Factories, 15(1), 1-18. doi: 10.1186/s12934-016-0603-7

Jeong H, Choi S-K, Ryu C-M and Park S-H (2019) Chronicle of a Soil Bacterium: Paenibacillus polymyxa E681 as a Tiny Guardian of Plant and Human Health. Front. Microbiol. 10:467. doi: 10.3389/fmicb.2019.00467

Hou, Y.H., Q.F. Wang, J.H. Shen, J.L. \& Miao, G.Y. (2008). Molecular identification of a halo tolerant bacterium NJ 82 from Antarctic Seaice and preliminary study on its salt tolerance. Microbiology, 35 (2008), pp. 486-490. doi: $\underline{10.1155 / 2011 / 615032}$

Kang, J., Amoozegar, A., Hesterberg, D., and Osmond, D. L. (2011). Phosphorus leaching in a sandy soil as affected by organic and inorganic fertlizer sources. Geoderma161,194201. doi: 10.1016/j.geoderma.2010.12.019

Kloepper JW, Leong J, Teintze M, Schroth MN (1980). Enhanced plant growth by siderophores produced by plant growthpromoting rhizobacteria. Nature 1980, 286:885-886.

https://doi.org/10.1038/286885a0

Kumar S., Stecher G., Li M., Knyaz C., and Tamura K. (2018). MEGA X: Molecular Evolutionary Genetics Analysis across computing platforms. Molecular Biology and Evolution 35:1547-1549. DOI: $\underline{10.1093 / \mathrm{molbev} / \mathrm{msy} 096}$
Marchesi, J. R., Sato, T., Weightman, A. J., Martin, T. A., Fry, J. C., Hiom, S. J., \& Wade, W. G. (1998). Design and evaluation of useful bacterium-specific PCR primers that amplify genes coding for bacterial $16 \mathrm{~S}$ rRNA. Applied and environmental microbiology, 64(2), 795799. DOI: 10.1128/AEM.64.2.795-799.1998

Padda, Kiran Preet; Puri, Akshit; Chanway, \& Chris P. (2017). Agriculturally Important Microbes for Sustainable Agriculture. Springer, Singapore. pp. 165-191. doi:10.1007/978-981-10-53436_6.

Ryu, CM, Farag MA, Hu CH, Reddy MS, Wei HX, Pare PW, Kloepper JW (2003). Bacterial volatiles promote growth in Arabidopsis. Proc Natl Acad Sci U S A 2003, 100:4927-4932. ttps://doi.org/10.1073/pnas.0730845100

Sepriana, C., Sumiati, E., Jekti, DSD, Zulkifli, L., (2020). Identifikasi dan Uji Daya Hambat Isolat Bakteri Endofit Bunga Tanaman Cengkeh (Syzygium aromaticum L.) Terhadap Bakteri Patogen. Jurnal Penelitian Pendidikan IPA, 6(1). pp. 101-106 DOI: 10.29303/jppipa.v6i1.340

Sharma, S.B., Sayyed, R.Z., Trivedi, M.H., and Gobi, T. A. (2013). Phosphate solubilizing microbes: sustainable approach for managing phosphorus deficiency in agricultural soils. Springerplus 2, 587-600. $\quad$ https://doi.org/10.1186/21931801-2-587

Taiz, L. and Zeiger, E. (2010) Plant Physiology. 5th Edition, Sinauer Associates, Inc., Sunderland.

Vasanthakumari, R. (2009). Practical Microbiology. New Delhi, BI Publications Pvt Ltd.

Xie, J. B., Du, Z., Bai, L., Tian, C., Zhang, Y., Xie, J. Y., \& Li, J. (2014). Comparative genomic analysis of $\mathrm{n} 2$-fixing and non-n 2-fixing Paenibacillus spp.: Organization, evolution and expression of the nitrogen fixation genes. PLoS Genetics, $\quad 10(3), \quad 1-17$ doi: 10.1371/journal.pgen.1004231

Xie, J., Shi, H., Du, Z., Wang, T., Liu, X., \& Chen, S. (2016). Comparative genomic and functional analysis reveal conservation of plant growth promoting traits in Paenibacillus polymyxa and 
Zulkifli, L. et al. (2020). Jurnal Biologi Tropis, 20 (3): 475 - 484

DOI: http://dx.doi.org/10.29303/jbt.v20i3.1730

its closely related species. Scientific Reports, 6(21329), 1-12. doi: 10.1038/srep21329

Zaidi, A., M.S.Khan, M. Ahemad \& M.Oves (2009). Plant Growth Promotion By Phosphate Solubilizing Bacteria. Acta Microbiologica Et Immunologica Hungarica, 56 (3), Pp. 263-284. DOI: https://doi.org/10.1556/amicr.56.2009.3.6
Zhu, F., Qu, L., Hong, X., and Sun, X. (2011). Isolation and Characterization of a Phosphate-Solubilizing Halophilic Bacterium Kushneria sp. YCWA18 from Daqiao Saltern on the Coast of Yellow Sea of China, Evidence-Based Complementary and AlternativeMedicine, vol. 2011, ID 615032, 6 p ages, 2011. doi.org/10.1155/2011/615032 